\title{
Evaluation of Superficial and Deep Capillary Plexa in Retinal Vein Occlusion Using Optical Coherence Tomography Angiography
}

\author{
ABD EL RAHMAN G. SALMAN, M.D.; SAMAH M. FAWZY, M.D.; TAREK M. ABD EL AZIZ, M.D. and \\ MAHA M.S.M. HIEBA, M.Sc.
}

The Department of Ophthalmology, Faculty of Medicine, Ain Shams University

\begin{abstract}
Background: Retinal Vein Occlusion (RVO) is the second most common cause of retinal vascular disease worldwide after diabetic retinopathy and its prevalence increases with age.

Aim of Study: To evaluate the retinal microvasculature in human subjects central and branch retinal vein occlusion using optical coherence tomography angiography (OCT angiography).
\end{abstract}

Patients and Methods: Twenty patients were recruited from the outpatient clinic in Al-Mashreq Eye Center. The study was performed during the time period between August 2018 and February 2019. OCTA (optical coherence tomography angiography) was performed at Mashreq Eye Center. All patients received a thorough explanation of the study design and provided their written consent.

Results: Our study revealed that there was no statistically significant difference between CRVO and BRVO group regarding demographic data, refraction, BCVA, FAZ, vessel density and thickness map. Also there was no statistically significant difference between CRVO group regarding FAZ, vessel density in 2 slices. There was no statistically significant difference between BRVO group regarding FAZ in 2 slices, vessel density in 2 slices.

Conclusions: We concluded that with the ability to noninvasively visualize vascular flow, OCTA could serve as a new diagnostic tool for current ophthalmic research and clinical practice.

Key Words: Central retinal vein occlusion - Branch retinal vein occlusion - Optical coherence tomography angiography on superficial capillary plexus and deep capillary plexus.

\section{Introduction}

RETINAL Vein Occlusion (RVO) is the second most common cause of retinal vascular disease worldwide after diabetic retinopathy, and its prev-

Correspondence to: Dr. Abd El Rahman G. Salman, The Department of Ophthalmology, Faculty of Medicine, Ain Shams University alence increases with age. Macular oedema is the main complication of well-perfused forms of RVO, limiting visual recovery in about half the cases $[1,2]$.

Recently a non-invasive technique, Spectraldomain Optical Coherence Tomography (SD OCT), has provided high-resolution images of both retinal and choroidal structures. SD OCT scans of the retina show bands of different reflectivity that appear to correspond to the histologic layers of the human retina, although strict correlation with histology has not yet been demonstrated [3,4]

A newly developed amplitude decorrelation algorithm provides information about blood flow by comparing 2 consecutive b-scans. The "ANGIOVUE" optical coherence tomography angiography (RTVUE XR; OPTOVUE, INC, FREMONT, CALIFORNIA, USA) is the first commercially available OCT device able to provide OCT angiography images [2].

As already, reported, the Split-Spectrum Amplitude Decorrelation Algorithm (SSADA) analyses OCT scans and enables distinction between static and non static tissue with a scale of flow signals of variable intensity $[\mathbf{5 , 6 ]}$. The SSADA algorithm also improves the signal-to-noise ratio in order to minimize bulk axial motions and artifacts within angiography scans. Thus, by calculating the amplitude of decorrelation signal coming from consecutive b-scans, blood flow can be clearly visualized [5-7].

It has already been demonstrated that a combination of c-scan OCT angiographies and corresponding conventional BSCANS provides clear images of both superficial and deep macular capillary plexa [8]. 
Areas of non perfusion following BRVO could be precisely delineated at several retinal levels using swept-source OCT microangiography. Moreover, De Carlo and associates described an area of diffuse capillary nonperfusion, continuous with the FAZ and telangiectatic vessels, in a case of CRVO [10]

\section{Aims of the work:}

To evaluate the retinal microvasculature in human subjects central and branch retinal vein occlusion using optical coherence tomography angiography (OCT angiography).

\section{Patients and Methods}

This is a cross sectional randomized descriptive study was carried out on a cohort of twenty Egyptian patients with known clinical diagnosis of central or branch vein occlusion. Patients were recruited from the outpatient clinic in Al-Mashreq Eye Center. The study was performed during the time period between August 2018 and February 2019. OCTA was performed at Mashreq Eye Center. All patients received a thorough explanation of the study design and provided their written consent.

Study population: All patients had the following: Inclusion criteria:

1- Patients with a known clinical diagnosis of CRVO and BRVO.

2- Subjects with well controlled hypertension, or hyperlipidemia were not excluded.

\section{Exclusion criteria:}

1- A history of ocular surgery (except for uncomplicated cataract surgery).

2- Previous laser photo coagulation or anti VEGF or corticosteroids.

3- Any patient with diabetic retinopathy.

4- Those with significant ophthalmological comorbidities other than CRVO or BRVO methods: All patients were subjected to the following:

1- Standard clinical examination and testing as appropriate for their clinical disease, including history taking.

2- Visual acuity assessment using auto refractometer, refraction and best corrected visual acuity (B.C.V.A.) assessment using Snellen chart.

3- Slit lamp examination of anterior chamber.

4- Fundus examination using slit lamp biomicroscopy with +90 Diopter lens.
5- Optical Coherence Tomography Angiography (OCTA) scanning for superficial and deep capillary plexa.

Optical Coherence Tomography Angiography (OCTA): OCTA images were obtained using the AngioVue (AngioVue; OptovueInc, Fremont, California, USA) machine and the incorporated AngioVue OCTA system. Algorithm used is SplitSpectrum Amplitude Decorrelation Angiography (SSADA). A-scan rate of the instrument is 70000 scans/second to compose OCTA volumes consisting of 304 X 304 A-scans. AngioVue system is provided by an orthogonal registration algorithm called Motion Correlation Technology (MCT) which minimizes motion artifacts produced by involuntary saccades and changes in fixation during data acquisition. The scans included in the study were of high signal strength more than 0.7 and they were carefully inspected for motion artifacts.

\section{Statistical analysis:}

The statistical methods that were used in this study, included; range, mean (x), Standard Dęviation (SD), percentage (\%), Chi-square test $\left(\chi^{2}\right)$ for comparison of percentages, $t$-student test for comparison of means and probability level $(p)$ for statistical significance. All $p$-values less than 0.05 were considered statistically significant. All statistical calculations were done using computer program's Microsoft Excel 2016 (Microsoft Corporation, NY) and SPSS (Statistical Package for the Social Science; SPSS Inc, Chicago, IL) version 18 for the Microsoft Windows.

\section{Results}

Table (1): Comparison between CRVO and BRVO group regarding refraction and BCVA.

\begin{tabular}{|c|c|c|c|c|}
\hline & $\begin{array}{c}\text { CRVO group } \\
\text { No. }=12\end{array}$ & $\begin{array}{c}\text { BRVO group } \\
\text { No. }=8\end{array}$ & $\begin{array}{c}\text { Test } \\
\text { value }\end{array}$ & $\underset{\text { value }}{p-}$ Sig \\
\hline $\begin{array}{l}\text { Sphere: } \\
\quad \text { Mean } \pm \text { SD } \\
\text { Range }\end{array}$ & $\begin{array}{l}0.21 \pm 1.71 \\
-3.25-3\end{array}$ & $\begin{array}{l}1.16 \pm 1.41 \\
-0.75-3.5\end{array}$ & $-1.199 \neq$ & $0.231 \mathrm{NS}$ \\
\hline $\begin{array}{l}\text { Cylinder: } \\
\quad \text { Mean } \pm \text { SD } \\
\text { Range }\end{array}$ & $\begin{array}{l}-0.98 \pm 0.77 \\
-3--0.5\end{array}$ & $\begin{array}{l}-0.97 \pm 0.98 \\
-2.5-0\end{array}$ & $-0.560 \neq$ & $0.576 \mathrm{NS}$ \\
\hline $\begin{array}{l}\text { Axis: } \\
\quad \text { Mean } \pm \text { SD } \\
\quad \text { Range }\end{array}$ & $\begin{array}{l}82.92 \pm 60.02 \\
5-165\end{array}$ & $\begin{array}{l}58.75 \pm 53.17 \\
0-140\end{array}$ & $-1.083 \neq$ & $0.279 \mathrm{NS}$ \\
\hline $\begin{array}{l}\text { BCVA: } \\
\quad \text { Mean } \pm \text { SD } \\
\quad \text { Range }\end{array}$ & $\begin{array}{l}0.64 \pm 0.24 \\
0.4-1\end{array}$ & $\begin{array}{l}0.47 \pm 0.32 \\
0.05-1\end{array}$ & $-1.137 \neq$ & $0.256 \mathrm{NS}$ \\
\hline $\begin{array}{l}\text { Air Puff: } \\
\quad \text { Mean } \pm \text { SD } \\
\quad \text { Range }\end{array}$ & $\begin{array}{l}14.08 \pm 2.54 \\
10-18\end{array}$ & $\begin{array}{l}14.13 \pm 2.03 \\
11-17\end{array}$ & $-0.039 \bullet$ & $0.970 \mathrm{NS}$ \\
\hline $\begin{array}{l}p \text {-value }>0.05: \\
p \text {-value }<0.05: \\
p \text {-value }<0.01:\end{array}$ & $\begin{array}{l}\text { Jon significan } \\
\text { ignificant. }\end{array}$ & & $\begin{array}{l}\text { Independe } \\
\text { Mann-Whi }\end{array}$ & $\begin{array}{l}t \text {-test. } \\
\text { ney test. }\end{array}$ \\
\hline
\end{tabular}


This table showing that there was no statistically significant difference between CRVO and BRVO group regarding refraction and BCVA.

Table (2): Comparison between CRVO and BRVO group regarding FAZ.

\begin{tabular}{|c|c|c|c|c|c|}
\hline FAZ 1 & $\begin{array}{c}\text { CRVO grou } \\
\text { No. }=12\end{array}$ & $\begin{array}{c}\text { BRVO group } \\
\text { No. }=8\end{array}$ & $\begin{array}{c}\text { Test } \\
\text { value• }\end{array}$ & $\begin{array}{c}p- \\
\text { value }\end{array}$ & Sig. \\
\hline $\begin{array}{l}\text { Area }\left(\mathrm{mm}^{2}\right): \\
\quad \text { Mean } \pm \mathrm{SD} \\
\quad \text { Range }\end{array}$ & $\begin{array}{l}0.11 \pm 0.06 \\
0.04-0.19\end{array}$ & $\begin{array}{l}0.08 \pm 0.05 \\
0.04-0.19\end{array}$ & 1.373 & 0.187 & NS \\
\hline $\begin{array}{l}\text { Perimeter }(\mathrm{mm} \\
\text { Mean } \pm \text { SD } \\
\text { Range }\end{array}$ & $\begin{array}{l}1.18 \pm 0.52 \\
0.6-1.97\end{array}$ & $\begin{array}{l}0.99 \pm 0.43 \\
0.6-1.97\end{array}$ & 0.893 & 0.384 & NS \\
\hline $\begin{array}{l}\text { Circularity: } \\
\text { Mean } \pm \text { SD } \\
\text { Range }\end{array}$ & $\begin{array}{l}0.65 \pm 0.06 \\
0.6-0.82\end{array}$ & $\begin{array}{l}0.64 \pm 0.06 \\
0.6-0.77\end{array}$ & 0.292 & 0.774 & NS \\
\hline
\end{tabular}

This table showing that there was no statistically significant difference between CRVO and BRVO group regarding FAZ.

Table (3): Comparison between CRVO and BRVO group regarding FAZ.

\begin{tabular}{|c|c|c|c|c|c|}
\hline FAZ2 & $\begin{array}{c}\text { CRVO group } \\
\text { No. }=12\end{array}$ & $\begin{array}{c}\text { BRVO group } \\
\text { No. }=8\end{array}$ & $\begin{array}{c}\text { Test } \\
\text { value• }\end{array}$ & $\begin{array}{c}p- \\
\text { value }\end{array}$ & Sig. \\
\hline $\begin{array}{l}\text { Area }\left(\mathrm{mm}^{2}\right): \\
\quad \text { Mean } \pm \text { SD } \\
\text { Range }\end{array}$ & $\begin{array}{l}0.11 \pm 0.06 \\
0.04-0.19\end{array}$ & $\begin{array}{l}0.07 \pm 0.05 \\
0.04-0.19\end{array}$ & 1.502 & 0.150 & NS \\
\hline $\begin{array}{l}\text { Perimeter }(\mathrm{mm}) \\
\text { Mean } \pm \mathrm{SD} \\
\text { Range }\end{array}$ & $\begin{array}{l}1.16 \pm 0.51 \\
0.6-1.97\end{array}$ & $\begin{array}{l}0.98 \pm 0.42 \\
0.66-1.97\end{array}$ & 0.834 & 0.415 & NS \\
\hline $\begin{array}{l}\text { Circularity: } \\
\text { Mean } \pm \text { SD } \\
\text { Range }\end{array}$ & $\begin{array}{l}0.64 \pm 0.07 \\
0.6-0.82\end{array}$ & $\begin{array}{l}0.6 \pm 0.03 \\
0.53-0.64\end{array}$ & 1.663 & 0.114 & NS \\
\hline
\end{tabular}

This table showing that there was no statistically significant difference between CRVO and BRVO group regarding FAZ.

\section{Discussion}

Retinal Vein Occlusion (RVO) is the second most common cause of retinal vascular diseases worldwide after diabetic retinopathy (Martinez et al., 2014) [12].

Many etiologies can be attributed to development of RVO, however, the most commonly accepted are thrombosis and embolism [11], resulting, in longstanding cases, in retinal ischemic changes [12].

Only few studies applying OCTA however quantified the findings and changes observed in the various retinal layers and in the choriocapillaris in eyes with RVOs $[\mathbf{8 , 1 2}]$.

We therefore conducted the present study to examine and evaluate the retinal microvasculature in human subjects central and branch retinal vein occlusion using optical coherence tomography angiography (OCT angiography).

Refraction and BCVA showed no statistically significant difference between CRVO and BRVO group.

Our results were same as Szigeti et al. [17], study to evaluate the association between ocular Axial Length (AL), Vitreous Chamber Depth (VCD) and both central (CRVO) and Branch Retinal Vein Occlusions (BRVO) using Optical Low Coherence Reflectometry (OLCR). Both eyes of 37 patients with unilateral CRVO and 46 patients with unilateral BRVO were enrolled in this study.

In the CRVO group, mean BCVA was $+0.70 \pm$ $0.63 \log$ MAR in the affected eyes and $+0.11 \pm 0.36$ $\log$ MAR in the unaffected fellow eyes. In the BRVO group, mean BCVAs of affected and fellow eyes were $+0.41 \pm 0.40 \log$ MAR and $+0.06 \pm 0.14$ $\log$ MAR, respectively [24].

In Lee et al., [24], study they stated that BCVA demonstrated a significant difference between 2 groups. The percentage of CRVO patients with Snellen BCVA $<0.2$ was higher and the mean logMAR BCVA of the CRVO patients was also significantly worse ( $p=0.025$ and 0.002 , respectively). The number of CRVO patients with a Snellen BCVA $\leq 0.2$ was $91(44.8 \%)$. The distribution of visual acuity was significantly different from that of the BRVO patients, which consisted of 118 patients with a Snellen BCVA $\leq 0.2(35.1 \%)$ [23] .

Our results revealed that the FAZ (FAZ 1,2) area was larger in CRVO than in BRVO ([FAZ 1= $\left.0.11 \pm 0.06 \mathrm{~mm}^{2} / \mathrm{FAZ} 2=0.11 \pm 0.06 \mathrm{~mm}^{2}\right]$ and $[\mathrm{FAZ}$ $\left.1=0.08 \pm 0.05 \mathrm{~mm}^{2} / \mathrm{FAZ} 2=0.07 \pm 0.05 \mathrm{~mm}^{2}\right]$ respectively) but, there was no statistically significant difference between CRVO and BRVO group regarding FAZ.

Seknazi et al., [18], study correlations in patients with retinal vein occlusion between the automatically quantified macular vascular densities in the superficial and Deep Capillary Plexus (DCP) obtained using Optical Coherence Tomography Angiography (OCTA) and the data from conventional examination, particularly visual acuity and peripheral retinal nonperfusion assessed using Fluorescein Angiography (FA). 
Their study was retrospective, observational study of patients with retinal vein occlusion who underwent a comprehensive ophthalmic examination including FA and OCTA using the AngioVue OCTA system version 2015.100.0.35 (OptovueRTVue XR 100; AVANTI, Inc, Fremont, CA).

Same as our results, they reported that the FAZ area was larger in CRVO than in BRVO $(0.768 \pm$ $0.623 \mathrm{~mm}^{2}$ and $0.515 \pm 0.581 \mathrm{~mm}^{2}$, respectively, in the SCP) [18]

Suzuki et al., [19], carried out a study on twelve patients (23 eyes; mean age, 64 years) were included (eight eyes with branch RVO, four with central RVO, and 11 unaffected fellow eyes. The Foveal Avascular Zone (FAZ) was evaluated with OCTA before and after treatment.

Their result was the same. They also found that the FAZ area in eyes with BRVO or CRVO was enlarged, especially in the deep capillary layer. Furthermore, the FAZ area was larger in eyes with CRVO than in those with BRVO.

Our study was in contrast with results of Werner et al. [20], they published a prospective crosssectional comparative study in 47 eyes of 47 patients was conducted to compare area of Foveal Avascular Zone (FAZ) in different retinal vascular layers in Optical Coherence Tomography Angiography (OCTA) and Fluorescein Angiography (FA) in patients with Retinal Vein Occlusion (RVO). The authors reported that there were no considerable differences in BRVO and CRVO.

Cabral et al., [21] also conducted a retrospective review of RVO patients without macular edema. Patients underwent a comprehensive ophthalmic examination including FA, spectral-domain OCT, and OCT-A. Both the SCP and DCP were evaluated using OCT-A. In the CRVO group, the median FAZ area was $0.49 \mathrm{~mm}^{2}$ (IQR: 0.37-0.61), while in the BRVO group, the median FAZ area was 0.54 $\mathrm{mm}^{2}$ (IQR: 0.36-0.80). They noted that there was no significant difference (all $p$-values were higher than 0.05) between the CRVO and BRVO groups in any of the analyzed parameters.

Regards ETDRS [ETDRS 1 and ETDRS 2] (vessel density) BRVO were reduced (7.55 \pm 3.89 and 5.69 \pm 4.66 ), but there was no statistically significant difference between CRVO and BRVO group regarding ETDRS [ETDRS 1 and ETDRS 2] (vessel density). There was no statistically significant difference between CRVO group regarding ETDRS (vessel density) in 2 slices. There was no statistically significant difference between BR-
VO group regarding ETDRS (vessel density) in 2 slices.

In accordance with these results in our study both superficial and deep plexus in BRVO were reduced $(7.55 \pm 3.89$ and $5.69 \pm 4.66)$, nevertheless as already suggested by other authors the deep plexus was more severely affected compared to the superficial plexus. In addition, in CRVO the vessel density was reduced only in the deep plexus compared to controls [22]

Cabral et al., biomarkers of peripheral nonperfusion in retinal venous occlusions using optical coherence tomography angiography stated that the mean whole en face density was $43.08 \pm 4.88$ in the SCP and $46.81 \pm 4.98$ in the DCP (total group) but with statistically significant difference CRVO group regarding whole en face density in the DCP and also there was statistically significant difference in BRVO group regarding whole en face density in the SCP [23]

Kia Tarassoly et al., [24] showed that vessel density and FAZ did not differ significantly between groups with and without cystoid change.

Lee et al., [24], showed that the mean DCP VD was similar for CRVO and BRVO eyes, regardless of the presence of collaterals. Interestingly, the mean SCP VD was lower for both CRVO and BRVO eyes with collaterals.

Other data from the study of Samara et al., [25] That reported lower vascular densities of superficial and deep retinal capillary densities in patients affected by BRVO compared to density values of the fellow eye that mean In eyes with BRVO, quantitative OCTA measurements confirm decreased vascular density in both the superficial and deep vascular networks. Moreover, vascular density and FAZ area appear to correlate with visual function.

This discrepancy may be due to the different inclusion criteria for macular edema or different OCTA platforms used.

The present study found no statistically significant difference between CRVO and BRVO group regarding Thickness map.

In agreement with the results of Lima et al., [26], study, they found that there were also no significant differences in foveal thickness and central subfield thickness between the two groups before and after resolution of macular edema. 
Age had been found as a definite factor across both disease entities (CRVO and BRVO) for predicting visual acuity outcomes, with younger age associated with better BCVA, there was significant relation between $\mathrm{BCVA}$ and age as with increasing age there is decreasing BCVA, also there was significant relation between BCVA and V.A. as with increasing V.A. there is increasing BCVA.

Younger patients may have better visual acuity outcomes due to generally healthier ocular tissue with improved likelihood for recovery following an acute insult such as a RVO: For example, irreparable damage to photoreceptors may be associated with age.

In agreement with Scott et al., [27], they reported that with younger age associated with a gain in 15 or more in visual acuity letter score in SCOREBRVO trial (with larger sample size).

Same results were found by Qin et al. [28], study, the age was younger in Group I than that in Group II (46.4y vs. 57.5y).

Our study showed a significant relation between BCVA and Perimeter ( $\mathrm{mm}$ ) of FAZ in 2 slices as increasing Perimeter $(\mathrm{mm})$ of FAZ with decreasing in BCVA.

In contrast with other study by Kang et al., [29], the area of superficial FAZ was positively correlated with BCVA (logMAR) $(r=0.303, p=0.014)$, and the superficial and deep parafoveal VDs were negatively correlated with BCVA ( $\log$ MAR) $(r=$ 20.366, $p=0.002 ; r=20.545, p, 0.001$, respectively). The univariate regression analysis showed that the BCVA ( $\log$ MAR) was associated positively with the area of superficial FAZ ( $p=0.014)$, and negatively with the superficial parafoveal VD $(p=0.002)$ and deep parafoveal VD $(p, 0.001)$. Multivariate linear regression analysis was performed using the significant factors obtained from the univariated analysis. The BCVA (logMAR) was associated negatively with deep parafoveal VD ( $r 2=0.297, p$ $0.001)$.

Several studies have reported that FAZ enlargement is correlated with visual acuity impairment, and disrupted perifoveal microcirculation is involved in the development of macular edema in patients with retinal vein occlusion [29].

These results indicate that the FAZ increases as the BCVA decreases, and the superficial and deep parafoveal VD decreases as the BCVA decreases.
This study found that here was no significant relation between BCVA and ETDRS (vessel density) in 2 slices.

A study by Durbin et al., [30], showed that there was a weak correlation between BCVA and vessel density (Spearman coefficient $=-0.28 ; p=.05$ ). There was a range of density observed within each ETDRS grade level, and the best variable with respect to vessel density was also correlated with BCVA and severity of DR.

Deng et al., [31], stated that there was a negative correlations between the logMAR BCVA and the whole vascular density in the SCP and DCP as well as the flow area of choriocapillaris were observed.

\section{Conclusions:}

Our study demonstrates the potential contribution of OCT angiography as a new noninvasive imaging technology that enables monitoring of the macular area in both edematous and ischemic RVO. OCT angiography can easily be repeated without any risk and could be a useful imaging modality in the management of macular edema secondary to RVO, particularly to determine treatment effects on the capillary bed.

\section{References}

1- ROGERS S., McINTOSH R.L., CHEUNG N., et al.: The Prevalence of Retinal Vein Occlusion: Pooled Data from Population Studies from the United States, Europe, Asia, and Australia. Ophthalmology, 117: 313-319.e1, 2010.

2- COSCAS F., GLACET-BERNARD A., MIERE A., et al.: Optical coherence tomography angiography in retinal vein occlusion: Evaluation of superficial and deep capillary plexa. Am. J. Ophthalmol., 161: 160-71, 2016.

3- MURAKAMI T., TSUJIKAWA A., MIYAMOTO K., e al.: Relationship between perifoveal capillaries and pathomorphology in macular oedema associated with branch retinal vein occlusion. Eye, 26: 771-80, 2012.

4- MURAOKA Y., TSUJIKAWA A., KUMAGAI K., et al.: Retinal Vessel Tortuosity Associated With Central Retinal Vein Occlusion: An Optical Coherence Tomography Study. Investig Opthalmology Vis. Sci, 55: 134, 2014.

5- JIA Y., TAN O., TOKAYER J., et al.: Split-spectrum amplitude-decorrelation angiography with optical coherence tomography. Opt. Express, 20: 4710-25, 2012.

6- TOKAYER J., JIA Y., DHALLA A.H. and HUANG D.: Blood flow velocity quantification using split-spectrum amplitude-decorrelation angiography with optical coherence tomography. Biomed Opt. Express, 4: 1909-24, 2013.

7- CHOI W., MOHLER K.J., POTSAID B., et al.: Choriocapillaris and Choroidal Microvasculature Imaging with Ultrahigh Speed OCT Angiography. PLoS One, 8: e81499, 2013. 
8- SPAIDE R.F., KLANCNIK J.M. and COONEY M.J. Retinal vascular layers imaged by fluorescein angiography and optical coherence tomography angiography. JAMA Ophthalmol., 133: 45-50, 2015.

9- De CARLO T.E., ROMANO A., WAHEED N.K. and DUKER J. S.: A review of optical coherence tomography angiography (OCTA). Int. J. Retin. Vitr., 1: 5, 2015.

10- CHALAM K.V. and SAMBHAV K.: Optical coherence tomography angiography in retinal diseases. J. Ophthalmic Vis. Res., 11: 84, 2016.

11- SUZUKI N., HIRANO Y., YOSHIDA M., et al.: Microvascular abnormalities on optical coherence tomography angiography in macular edema associated with branch retinal vein occlusion. Am. J. Ophthalmol., 161: 126-32, 2016 b.

12- HUANG Y., ZHANG Q., THORELL M.R., et al.: Sweptsource OCT angiography of the retinal vasculature using intensity differentiation-based optical microangiography algorithms. Ophthalmic Surgery, Lasers Imaging Retin, 45: 382-9, 2014.

13- LAM H.D., LAHEY J.M., KEARNEY J.J., et al.: Young patients with branch retinal vein occlusion: A review of 60 cases. Retina, 30: 1520-3, 2010.

14- RATH E.Z., FRANK R.N., SHIN D.H. and KIM C.: Risk factors for retinal vein occlusions: A case-control study. Ophthalmology, 99: 509-14, 1992.

15- STAMPER R.L., LIEBERMAN M.F. and DRAKE M.V.: Secondary angle-closure glaucoma. In: Becker-Shaffer's Diagnosis and Therapy of the Glaucomas. Elsevier, bll 212-38, 2009.

16- LEE J.Y., YOON Y.H., KIM H.K., et al.: Baseline characteristics and risk factors of retinal vein occlusion: A study by the Korean RVO Study Group. J. Korean Med. Sci., 28: 136-44, 2013.

17- SZIGETI A., SCHNEIDER M., ECSEDY M., et al.: Association between retinal vein occlusion, axial length and vitreous chamber depth measured by optical low coherence reflectometry. BMC Ophthalmol., 15: 45, 2015.

18- SEKNAZI D., COSCAS F., SELLAM A., et al.: Optical Coherence Tomography Angiography In Retinal Vein Occlusion: Correlations Between Macular Vascular Density, Visual Acuity, and Peripheral Nonperfusion Area on Fluorescein Angiography. Retina, 38: 1562-70, 2018.

19- SUZUKI N., HIRANO Y., TOMIYASU T., et al.: Retinal hemodynamics seen on optical coherence tomography angiography before and after treatment of retinal vein occlusion. Investig. Ophthalmol. Vis. Sci., 57: 5681-7, 2016a.

20- WERNER J.U., BÖHM F., LANG G.E., et al.: Comparison of foveal avascular zone between optical coherence tomography angiography and fluorescein angiography in patients with retinal vein occlusion. PLoS One, 14, 2019.

21- CABRAL D., COSCAS F., GLACET-BERNARD A., et al.: Biomarkers of peripheral nonperfusion in retinal venous occlusions using optical coherence tomography angiography. Transl. Vis. Sci. Technol., 8, 2019.

22- MASTROPASQUA R., TOTO L., Di ANTONIO L., et al.: Optical coherence tomography angiography microvascular findings in macular edema due to central and branch retinal vein occlusions. Sci. Rep., 7: 40763, 2017.

23- CABRAL D., COSCAS F., GLACET-BERNARD A., et al.: Biomarkers of peripheral nonperfusion in retinal venous occlusions using optical coherence tomography angiography. Transl. Vis. Sci. Technol., 8, 2019.

24- LEE H.E., WANG Y., FAYED A.E. and FAWZI A.A.: Exploring the relationship between collaterals and vessel density in retinal vein occlusions using optical coherence tomography angiography. PLoS One, 14: e0215790, 2019.

25- SAMARA W.A., SHAHLAEE A., SRIDHAR J., et al.: Quantitative optical coherence tomography angiography features and visual function in eyes with branch retinal vein occlusion. Am. J. Ophthalmol., 166: 76-83, 2016.

26- LIMA V.C., YEUNG L., CASTRO L.C., et al.: Correlation between spectral domain optical coherence tomography findings and visual outcomes in central retinal vein occlusion. Clin. Ophthalmol., 5: 299-305, 2011.

27- SCOTT I.U., VANVELDHUISEN P.C., ODEN N.L., et al.: Baseline predictors of visual acuity and retinal thickness outcomes in patients with retinal vein occlusion: Standard Care Versus COrticosteroid for REtinal Vein Occlusion Study report 10. Ophthalmology, 118: 345-52, 2011.

28- QIN Y.W., YU J. and ZHANG Q.: Characteristics of retinal vein occlusion with final vision better than 78 letters after sequential therapy with ranibizumab and triamcinolone acetate. Int. J. Ophthalmol., 10: 271, 2017.

29- KANG J.W., YOO R., JO Y.H. and KIM H.C.: Correlation of microvascular structures on optical coherence tomography angiography with visual acuity in retinal vein occlusion. Retina, 37: 1700-9, 2017.

30- DURBIN M.K., AN L., SHEMONSKI N.D., et al.: Quantification of retinal microvascular density in optical coherence tomographic angiography images in diabetic retinopathy. JAMA Ophthalmol., 135: 370-6, 2017.

31- DENG Y., CAI X., ZHANG S., et al.: Quantitative Analysis of Retinal Microvascular Changes after Conbercept Therapy in Branch Retinal Vein Occlusion Using Optical Coherence Tomography Angiography. Ophthalmologica, 1-12, 2019. 


\section{تقييم حالة الآوعية الدموية السطحية والعميقة

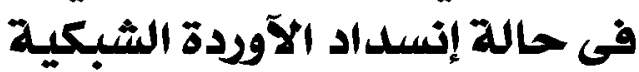

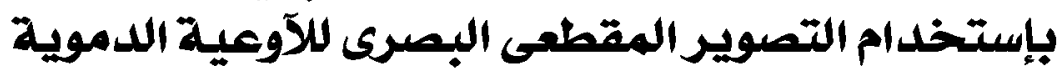

يعد إنسداد الوريد الثبكى (RVO) هو السبب الثانى الآكثر شيوعاً لمرض الآوعية الدموية الثبكية فى جميع آنحاء العالم بعد إعتلال الشبكية السكرى، ويزيد إنتشاره مع تقدم العمر.

التصوير المقطعى البصرى للآوعية الدموية (OCTA) عبارة عن تقنية جديدة تستخدم تباين الحركة بدلاً من الصبغة لإنشاء صود الآوعية الدموية خاصة فى شبكية العين التى لا لمكن حالياً دون حقن صبغة الدمبية التباين.

الغرض من هذه الدراسة هو تقييم الآوعية الدموية السطحية والعميقة فى شبكية العين مع إنسداد الوريد الشبكى بإستخدام التصوير المقطعى البصرى للآوعية الدموية.

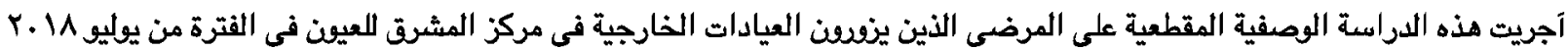

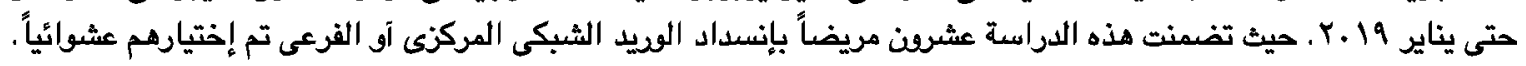

آوضحت نتائج هذه الدراسة آنه لا يوجد فرق ذى دلالة إحصائية بين مجموعة تخثر الوريد الشبكى المركزى بما يتعلق منطقة الآوعية الدموية

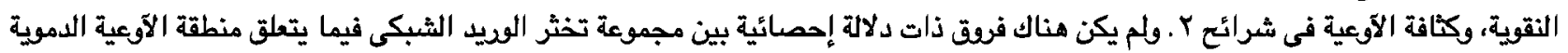

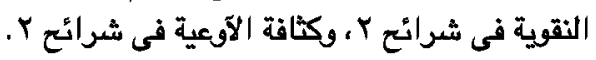

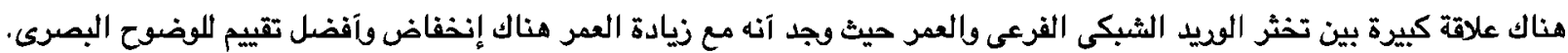

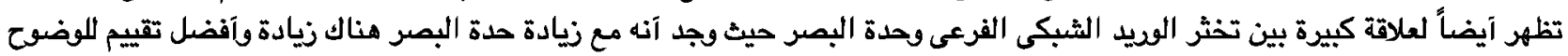

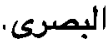

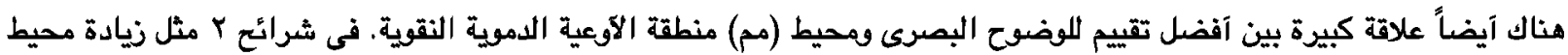

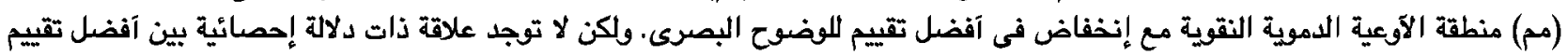
اللوضوح البصرى وكثافة الآوعية.

لم يكن هناك فرق ذى دلالة إحصائية بين مجموعة تخثر الوريد الثبكى الفرعى فيما يتطلق آفضل تقييم للوضوح البصرى والعمر، حدة البصر، الإنكسار، منطقة الآوعية الدموية النقوية وكثافة الآوعية. 